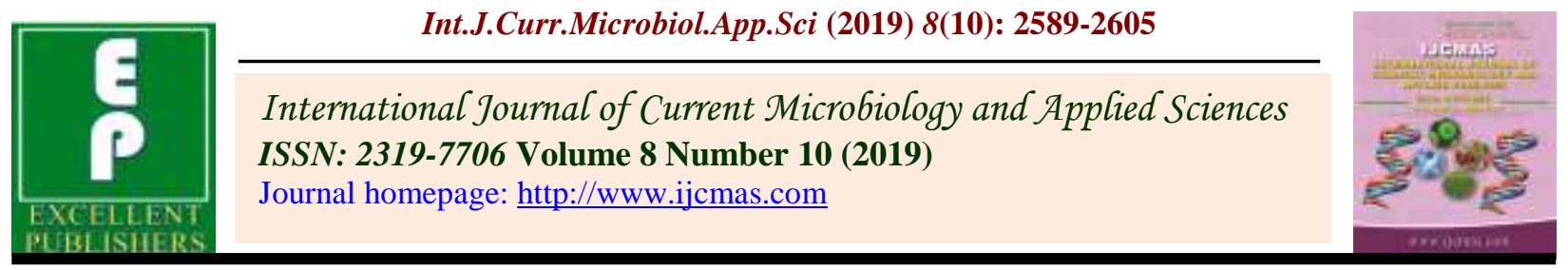

Original Research Article

https://doi.org/10.20546/ijcmas.2019.810.300

\title{
Effect of Growing Media and Plant Growth Regulators on Rooting of Different Types of Stem Cuttings in Acid-Lime Cv. Kagzi
}

\author{
Ashis Malakar ${ }^{1 *}$, D. P. Prakasha ${ }^{2}$, H. Kulapati ${ }^{3}$, Sanjeevraddi G. Reddi ${ }^{4}$, \\ S. G. Gollagi ${ }^{5}$, N. Anand ${ }^{6}$ and P. Satheesh ${ }^{6}$ \\ ${ }^{1}$ College of Horticulture, UHS Bagalkot-587 104, India \\ ${ }^{2}$ Department of Fruit Sciences, College of Horticulture, Munirabad-583 233, \\ Koppal (Tq and Dist), Karnataka State, India \\ ${ }^{3}$ Department of Fruit Sciences, Bagalkot-587 104, India \\ ${ }^{4}$ Department of Agronomy, College of Horticulture, UHS Bagalkot-587 104, India \\ ${ }^{5}$ Department of Plant Physiology, College of Horticulture, UHS Bagalkot-587 104, India \\ ${ }^{6}$ Department of Fruit Sciences and Farm superintendent, College of Horticulture, UHS \\ Bagalkot-587 104, India \\ *Corresponding author
}

\begin{abstract}
A B S T R A C T
Keywords

Acid lime, Kagzi lime, PGRs, cuttings, Rooting media, Polyhouse

\section{Article Info}

Accepted:

18 September 2019

Available Online:

10 October 2019

The experiment was conducted in a polyhouse to study the effect of types of stem cuttings [shoot tip $\left(\mathrm{C}_{1}\right)$, semi-hardwood $\left(\mathrm{C}_{2}\right)$ and hardwood cuttings $\left(\mathrm{C}_{3}\right)$ ], growing media [sand $\left(\mathrm{M}_{1}\right)$, soilrite $\left(\mathrm{M}_{2}\right)$, soil mixture $\left(\mathrm{M}_{3}\right)$ and cocopeat $\left(\mathrm{M}_{4}\right)$ ] and plant growth regulator [IBA$0 \mathrm{ppm}\left(\mathrm{G}_{0}\right), 500 \mathrm{ppm}\left(\mathrm{G}_{1}\right), 1000 \mathrm{ppm}\left(\mathrm{G}_{2}\right), 1500 \mathrm{ppm}\left(\mathrm{G}_{3}\right)$ solution and rootex powder $\left(\mathrm{G}_{4}\right)$ ], on rooting and shooting parameters of acid-lime (Citrus aurantifolia (Christm.) Swingle) Cv. Kagzi lime cuttings. In the present study, hardwood cuttings, cocopeat and $500 \mathrm{ppm}$ IBA was better to induce more shooting and rooting parameters in acid lime cuttings. Among the interaction of treatments, the minimum days were taken to sprout was recorded in the treatment $T_{11}\left(C_{3}\right.$ Hardwood cutting $+M_{1}$ Sand $+G_{0}$ IBA 0 ppm $)$ with 16.83 days. Further, $T_{57}\left(C_{3}\right.$ Hardwood cutting $+M_{4}$ Cocopeat $+G_{1}$ IBA 500 ppm $)$ gave the best response with respect percentage of sprouted cuttings ( 47.22 per cent), number of sprouts at 30, 60 and 90 DAP $(4.6,24.00$ and 7.40, respectively), length of shoots at 90 DAP $(14.59 \mathrm{~cm})$, average fresh weight $(13.52 \mathrm{~g})$ and dry weight $(10.19 \mathrm{~g})$, number of primary root $(11.10)$, length of longest root $(15.47 \mathrm{~cm})$ and percentage of rooted cuttings (44.44\%). The results obtained from this study can be used to develop a protocol for production of quality planting material of acid lime through cuttings.
\end{abstract}

\section{Introduction}

The acid lime [Citrus aurantifolia (Christm.) Swingle] is the most important fruit of India, belongs to the family Rutaceae. Limes and lemons are believed to have originated in north eastern India, adjoining portions of Burma or northern Malaysia and have followed the general path westward to the Mediterranean basin and then to the western 
hemisphere. It is the rich source of vitamin $\mathrm{C}$. It also contains vitamin $\mathrm{B}$, pectin, minerals and other nutritive substance which are required for human health. Lime juice is used for scurvy diseases. They also have laxative effect on the digestive system. In India, citrus is grown in 976 thousand hectares with the production of 11717 thousand metric tonnes having productivity 8.8 metric tonnes/ha and acid lime is grown in 230 thousand hectares with the production of 2273 thousand metric tonnes having productivity 10.8 tonnes/ha (Anonymous, 2017).

Generally, acid lime is regenerated through seeds, but there is a problem of nonuniformity of progeny and high chance of viral disease contamination by this method (Babu, 2001). Also, it is not advisable to use seeds for commercial planting because these seeds do not produce true fruits. Therefore, it is advisable to avoid seedlings for commercial plantation. For overcoming this problem, the vegetative propagation is vital to produce citrus plants having desirable characters as mother plant and they are propagated true-totype from cuttings, budding, grafting, layering, etc (Seran and Umadevi, 2011). However, vegetative multiplication through cutting is only cheap, practicable and widely used option for augmenting natural regeneration and for large scale cultivation programmes. Owing to high intensity of polyembroyony (90-100\%) and least chance of contamination of viral diseases (Babu, 2001) in Kagzi-lime, the stem cutting appears as most suitable method for regeneration of the species. Further, it is reported that juvenile stage of plants can be decreased through stem cutting technique and the time of nursery development can also be reduced. It is inexpensive, rapid and simple and does not require the special techniques as required in other vegetative methods. The success of stem cuttings depend on many factors associated with plants such as age of the mother plant, parts used of tree, time of planting, rainfall, humidity, temperature, rooting media and after care (Frey et al., 2006). Bhatt and Tomar (2011) recorded highest sprouted bud $(68.50 \%)$ in $500 \mathrm{ppm}$ followed by $1000 \mathrm{ppm}$ $(53.67 \%)$, while lowest $(36.55 \%)$ occurred in control. Singh et al., (2015) stated that Soil+Sand+FYM improved survival percentage $(82.33 \%)$, average dry weight of cutting $(8.05 \mathrm{~g})$ and reduced the thickness of roots $(1.08 \mathrm{~mm})$ while higher rooting percentage $(64.26 \%)$, number of primary (9.03) and secondary roots (16.67), average length of longest root $(7.81 \mathrm{~cm})$, length of sprout $(7.10 \mathrm{~cm})$ and average fresh weight of cutting $(12.24 \mathrm{~g})$ were recorded with Soil+Sand+Cocopeat in case of lemon (Citrus limon Burm.) cv. pant lemon-1. Hence, it appears, rooting ability changes with genotype, rooting media, PGRs, etc., Hence, the present research was formulated to assess effect of growing media and plant growth regulators on rooting of different types of stem cuttings in acid-lime cv. Kagzi lime.

\section{Materials and Methods}

The investigation was conducted during the year 2018-19 at College of Horticulture, Bagalkot, University of Horticultural Sciences, Navanagar, Bagalkot Karnataka587104 located at $16.16^{\circ}$ North latitudes, $75.62^{\circ}$ East longitudes and an altitudes of 678 meter above the from mean sea level to standardise the hi-tech propagation protocol in acid lime (Citrus aurantifolia Swingle) through cuttings.

\section{Plant materials and propagation conditions}

Acid lime cv. Kagzi lime trees grown in the orchard of the Department of Fruit Science, College of Horticulture, Bagalkot and MHREC, University of Horticultural Sciences, Bagalkot were selected for this experiment on the basis of their uniformity in appearance, 
growth habit, free from visual symptoms of pests and disease occurrence. The propagation conditions provided for the rooting of the cuttings was Polyhouse

\section{Preparation of cuttings, media and PGRs}

Acid lime (Citrus aurantifolia Swingle) stem cuttings were taken from healthy mother plants. Three types of stem cuttings viz., shoot tip $\left(\mathrm{C}_{1}\right)$, semi-hardwood $\left(\mathrm{C}_{2}\right)$ and hardwood cuttings $\left(\mathrm{C}_{3}\right)$ of 15 to $20 \mathrm{~cm}$ long, containing about 6 to 9 buds were used. Different growing media such sand $\left(\mathrm{M}_{1}\right)$, soilrite $\left(\mathrm{M}_{2}\right.$; Mixture of 75 per cent Irish peat moss and 25 per cent horticulture grade perlite), soil mixture (M3; mixture of fine garden soil, sand and farmyard manure at a ratio of 2:1:1) and cocopeat $\left(\mathrm{M}_{4}\right)$ were used. Different levels of concentrations of Indole butyric acid of $0 \mathrm{ppm}$ $\left(\mathrm{G}_{0}\right), 500 \mathrm{ppm}\left(\mathrm{G}_{1}\right), 1000 \mathrm{ppm}\left(\mathrm{G}_{2}\right), 1500 \mathrm{ppm}$ $\left(\mathrm{G}_{3}\right)$ solution and rootex powder $\left(\mathrm{G}_{4}\right)$ were used. To prepare PGR solution, required quantity of IBA powder was dissolved in little quantity of $0.1 \quad \mathrm{~N} \quad \mathrm{NaOH}$ and stirred thoroughly until the power gets dissolved completely. Later the final volume was made up to 1 litre by adding distilled water.

\section{Containers}

For the purpose of planting of cutting for rooting, 18 cavity plastic pro trays were being used having a thickness of $1 \mathrm{~mm}$ to contain the required media. The garden pots filled with desirable media were also used for planting the different types of stem cuttings.

\section{Planting of cutting}

The prepared cuttings were ready to be treated and for planting. One third basal portion of the cuttings were dipped in aqueous solution of IBA according to concentration and planted in the pro trays and garden pots by inserting twothird portion of it. The planted cuttings were irrigated regularly depending upon soil moisture conditions.

\section{Observation recorded}

The observation recorded under the present study were days taken for sprout initiation, sprouting percentage, number of sprouts per cutting, number of leaves per cutting, Shoot length at 30, 60 and 90 days after planting. Further, fresh weight (of entire cutting), dry weight (of entire cutting after hot air oven drying for 24 hours at $36^{\circ} \mathrm{C}$ ), number of primary roots, length of the longest root and rooting percentage was recorded after 90 days after planting. The observations were expressed in per cent, $\mathrm{cm}$, gram, day etc units as necessity.

\section{Design and statistical analysis}

The present study has been laid out in three factorial completely randomised design (FCRD) with sixty treatments sufficient with twice replications. Every treatment contained 18 kagzi lime cuttings. The data recorded for all the parameters were subjected to ANOVA by following completely randomized design (CRD) at 5 per cent level of significance as suggested by Gomez and Gomez (1980). The analysis has been done in Web Agri-Stat Package (WASP 2.0) developed by ICAR Research Complex, Goa.

\section{Results and Discussion}

Propagation is broadly followed to multiply plants of desired constitution and maintain their purity for commercial exploitation in many fruit crops. The art of propagation by vegetative method has gained popularity in the field of horticulture in recent years. Many of the horticultural crops which are found to be difficult to root are made to root easily by using plant growth regulators, growing media and propagation conditions. Among the 
methods of vegetative propagation, use of cuttings is one of the important practices. In the present study, an attempt has been made to discuss the result obtained during the course of investigation in order to clarify the objectives of the present study. The findings of this experiment clearly indicated that the importance of proper selection of type of cutting, rooting media, plant growth regulator and propagation conditions for achieving success in regeneration of cutting in acid lime.

\section{Effect on days taken for sprout initiation}

In the present study, the hardwood cuttings had taken significantly lesser days for sprout initiation as compared to semi hardwood and shoot tip cuttings (Table 1) which may be due to prevention of down-word translocation of carbohydrate and accumulation of higher level of endogenous and exogenous auxins. Hardwood cuttings had more dry matter and more accumulates which might have resulted earliest completion of physiological process involved in sprouting. Further, time taken for sprouting was almost similar in all media but cocopeat produced earliest sprouting, longer and thicker sprouts due to optimum nutrient uptake and enhanced availability of nutrients and growth promoting substances. IBA at a lower concentration was found to be better to induct early sprouting. Interaction of different types of cutting, rooting media and the various doses of IBA significantly affected the days taken for sprout initiation, in acid lime cuttings (Table 3). Minimum days taken for sprouting was recorded in $\mathrm{T}_{11}\left(\mathrm{C}_{3}\right.$ hardwood cutting $+\mathrm{M}_{1}$ sand $+\mathrm{G}_{0}$ IBA 0 ppm) with 16.83 days and the maximum days taken for sprout initiation was recorded in treatment $\mathrm{T}_{22}$ $\left(\mathrm{C}_{2}\right.$ semi-hardwood cutting $+\mathrm{M}_{2}$ soilrite $+\mathrm{G}_{1}$ IBA $500 \mathrm{ppm}$ ) of about 29.833 days, which may be because of soil temperature maintained by sand (Table 3). However, Kareem et al., (2016) reported that the minimum days taken for sprout initiation was about 22 days in the softwood cuttings of Gola variety of guava treated with 4000 ppm IBA. But similar results like in the present study have been reported by Kumar et al., (1995) in lemon cv. Baramasi.

\section{Effect on sprouting percentage}

In the present study, significantly higher percentage of sprouting was recorded in the hardwood cuttings (Table 1) as compared to semi hardwood and shoot tip cuttings which may be due to better utilization of stored carbohydrate, nitrogen and other factor with the aid of growth regulator, high percentage of sprouting was observed in soilrite and cocopeat media compared to other media due to optimum uptake of growth regulator and high percentage of sprouting was observed in cuttings treated with 500 ppm IBA. The interaction of these parameters was significant and highest sprouting had been observed in treatment $\mathrm{T}_{57}\left(\mathrm{C}_{3}\right.$ hardwood cutting+ $\mathrm{M}_{4}$ cocopeat $+\mathrm{G}_{1}$ IBA 500 ppm) with 47.22 per cent, whereas lowest sprouting percentage had been observed in treatment $T_{31}\left(C_{1}\right.$ shoot-tip cuttings $+\mathrm{M}_{3}$ soil mixture $+\mathrm{G}_{0}$ IBA $0 \mathrm{ppm}$ ) with 5.55 percent (Table 3). Similarly, Siddiqui and Hussain (2007) had recorded maximum sprouting percentage of 48.25 per cent in the hardwood cuttings of Ficus hawaii treated with $4000 \mathrm{ppm}$ of IBA. The results of present study were also similar with the finding of Bhatt and Tomar (2011) in Citrus auriantifolia Swingle (Kagzi-lime).

\section{Effect on number of sprouts}

In the present study, significantly, more number of sprouts per cutting at 30,60 and 90 days after planting was recorded in the hardwood cuttings followed by semi hardwood and shoot tip cuttings (Table 1) which might be due to the facts that cuttings taken from lime crop was noted to have the maximum nutrient and the cuttings made had 
used these stored nutrients for good vegetative growth, the highest number of sprouts was observed in soil mixture media and the highest sprouts were recorded in 500 ppm IBA. However, the number of sprouts per cutting at 90 DAP was less as compared to 60 and 30 DAP as result of drop of many sprouts, which may be because of utilization of reserved food available in the cuttings. At 90 DAP only few sprouted shoots remained on the cutting and showed elongation. Similar results were also reported by Mehta et al., (2018) with highest number of sprouts per cutting (4.66) after 90 DAP in the cuttings treated with 500ppm IBA in pomegranate (Punica granatum L.). In this study, the number of sprouts per cutting was significantly affected by the interaction of different factors (Fig. 1). The highest number of sprouts was obtained after 90 DAP in the treatment $\mathrm{T}_{57}\left(\mathrm{C}_{3}\right.$ hardwood cutting+ $\mathrm{M}_{4}$ cocopeat $+\mathrm{G}_{1}$ IBA 500 ppm) with 7.40 sprouts per cutting which was on par with the treatment $\mathrm{T}_{56} \quad\left(\mathrm{C}_{3}\right.$ hardwood cutting+ $\mathrm{M}_{4}$ cocopeat $+\mathrm{G}_{0}$ IBA 0 ppm) with 7.20 sprouts per cutting. The lowest number of sprouts per cutting were recorded in the treatment $T_{34}\left(C_{1}\right.$ shoot-tip cuttings $+\mathrm{M}_{3}$ soil mixture $+\mathrm{G}_{3}$ IBA $1,500 \mathrm{ppm}$ ) with 1.50 sprouts. Similar, results reported by Singh et al., (2015) have shown 2.58 sprouts per cuttings in hardwood cuttings of lemon cv. Pant Lemon-1 planted in soil+sand+vermicompost medium. Further, Hussain et al., (2016) had attained maximum number of sprouts in soft wood cuttings whereas tip cutting had shown lowest sprouts per cutting. It appears that degree of response in different type of cuttings depends on the propagation conditions also. Our results were also in close confirmity with the results reported by El-Shazly et al., (1994) in Eureka lemon and El-Soukari loquat.

\section{Effect on number of leaves}

Number of leaves per cutting among the treatments was affected significantly by interaction of different type of cutting, growing media and IBA. There was increase in number of leaves up to 90 DAP (Table 1) which might be due to the growth favoured by the nutrients present in media at root levels, resulting more number of leaves per cuttings.

The highest average number of leaves per cutting was observed in the hardwood cuttings followed by semi-hardwood and shoot tip cuttings as it had more dry matter, highest average number of leaves was observed in the cuttings planted in soilrite as it provided good aeration in the root zone and better nutrient supply to the cuttings and highest average number of leaves was recorded in $500 \mathrm{ppm}$ of IBA.

The number of leaves per cutting at 90 days after planting was found to be significantly affected by interaction of different factors studied (Fig. 2). The highest average number of leaves per cutting at 90 DAP had been recorded in $\mathrm{T}_{57}$ treatment $\left(\mathrm{C}_{3}\right.$ hardwood cutting $+\mathrm{M}_{4}$ cocopeat $+\mathrm{G}_{1}$ IBA $500 \mathrm{ppm}$ ) with 25.3 leaves which is on par with the treatment $\mathrm{T}_{52}\left(\mathrm{C}_{2}\right.$ semi-hardwood cutting $+\mathrm{M}_{4}$ cocopeat $+\mathrm{G}_{1}$ IBA 500 ppm) with 25.25 leaves, whereas, lowest average number of leaves per cutting was recorded in the treatment $T_{21}\left(C_{2}\right.$ semi-hardwood cutting $+\mathrm{M}_{2}$ soilrite $+\mathrm{G}_{0}$ IBA 0 ppm) with 8.38 leaves. The number of leaves per cutting was varied with treatments which may be because of the interaction of the factors. Similarly, Singh (2014) obtained better results with respect to average number of leaves (25.33) in hardwood cuttings of Punica granatum L. However, Sadiq (1991) attained maximum number of leaves (21.25) in semi-hardwood stems cuttings of peach cv. Early Grande treated with 400 ppm IBA. Mehta et al., (2018) briefed that $\mathrm{C}_{1}$ (500ppm IBA) treatment was beneficial for the rooting in pomegranate (Punica granatum L.) cuttings with respect to number of leaves on new shoots (10.66). 


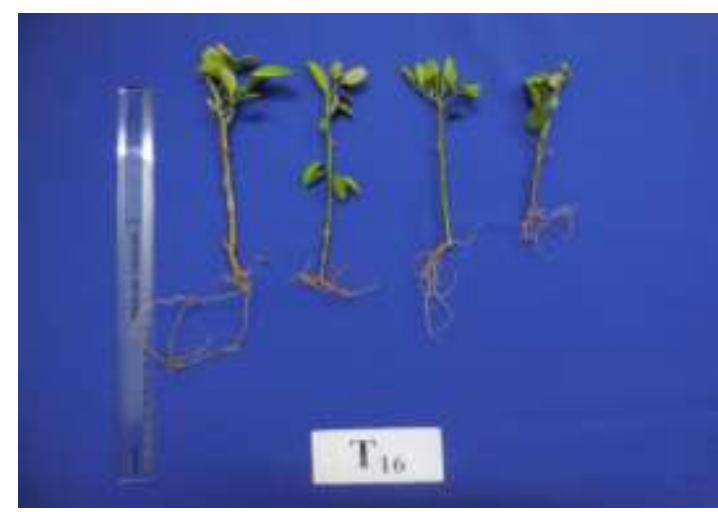

Figure 1A: $C_{1}$ Shoot-tip cuttings $+M_{2}$ Soilrite $+G_{0}$ IBA 0 ppm

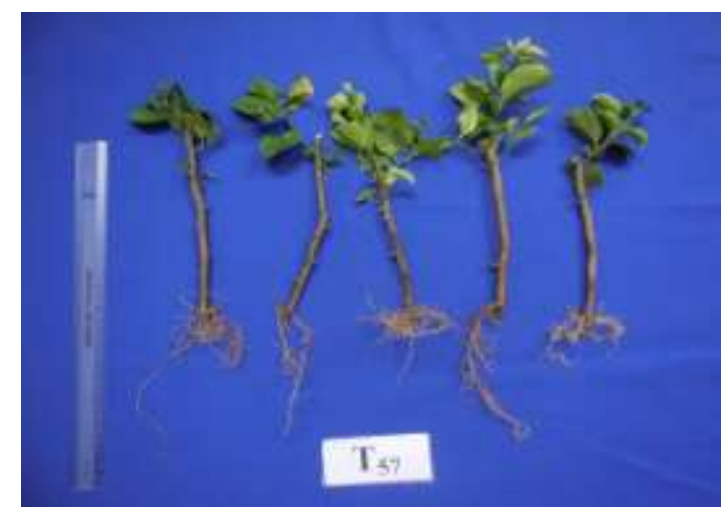

Figure 1C: $\mathrm{C}_{3}$ Hardwood cutting+ $\mathrm{M}_{4}$ Cocopeat + G1 IBA 500 ppm

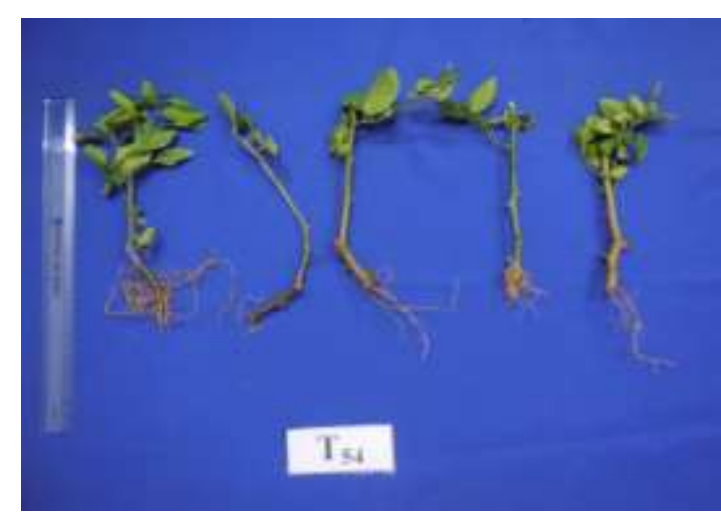

Figure 1E: $C_{2}$ Semi-hardwood cutting $+M_{4}$ Cocopeat + G3 IBA 1,500 ppm

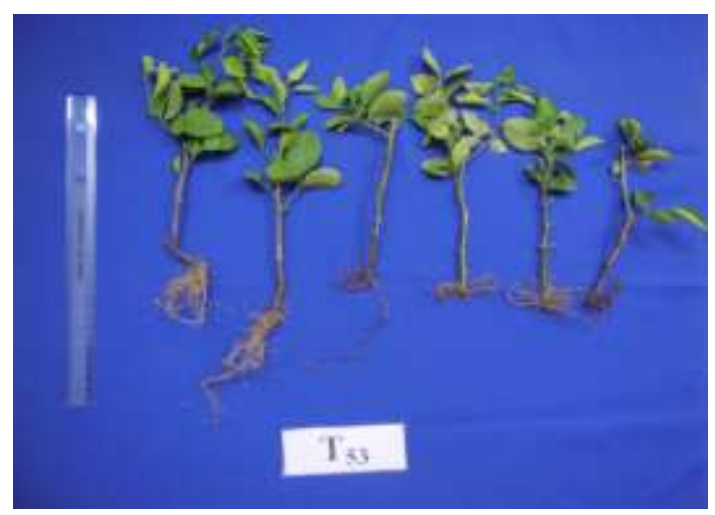

Figure 1B: $\mathrm{C}_{2}$ Semi-hardwood cutting $+\mathrm{M}_{4}$ Cocopeat $+\mathrm{G}_{2}$ IBA 1,000 ppm

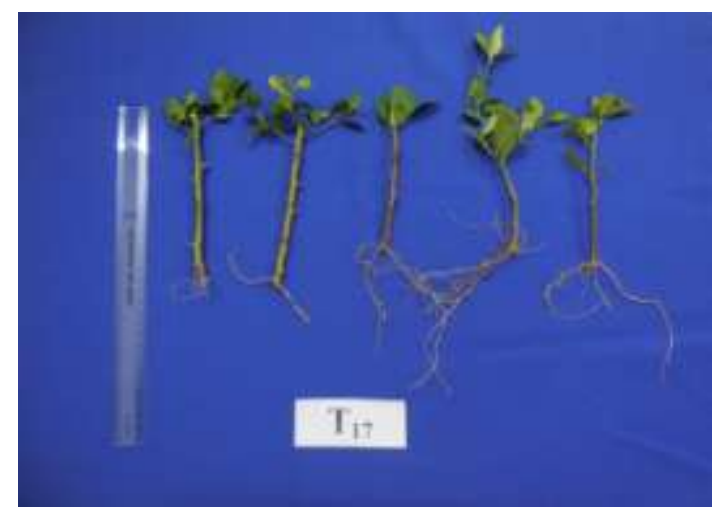

Figure 1D: $C_{1}$ Shoot-tip cuttings+ $M_{2}$ Soilrite $+G_{1}$ IBA 500 ppm

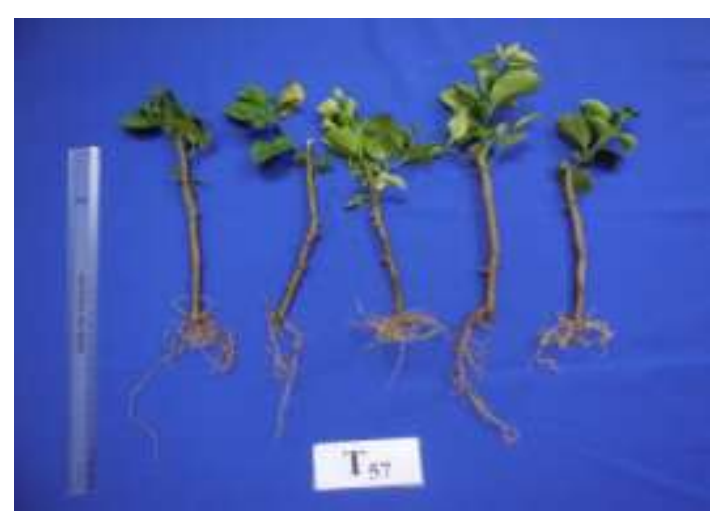

Figure 1F: $\mathrm{C}_{3}$ Hardwood cutting $+\mathrm{M}_{4}$ Cocopeat $+\mathrm{G}_{1}$ IBA 500 ppm

Plate 1: Best treatments with respect to shoot growth (Figure 1A-1C) and root growth parameters (Figure 1D-1F) in the study of effect of type of cutting, growing media and plant growth regulators on rooting ability of cuttings. 
Table.1 Shoot parameters as influenced by types of cuttings, growing media and various concentrations of plant growth regulators

\begin{tabular}{|c|c|c|c|c|c|c|c|c|}
\hline \multirow[t]{2}{*}{ Factors } & \multirow{2}{*}{$\begin{array}{l}\text { Days taken for } \\
\text { sprout initiation }\end{array}$} & \multirow{2}{*}{$\begin{array}{l}\text { Sprouting } \\
\text { percentage }\end{array}$} & \multicolumn{3}{|c|}{ Number of sprouts per cutting } & \multicolumn{3}{|c|}{ Number of leaves per cutting } \\
\hline & & & 30 DAP & 60 DAP & 90 DAP & 30 DAP & 60 DAP & 90 DAP \\
\hline $\mathrm{C}_{1}$ Shoot-tip cuttings & 24.32 & 18.19 & 2.54 & 3.80 & 3.10 & 5.85 & 9.47 & 14.46 \\
\hline $\begin{array}{c}\mathrm{C}_{2} \text { Semi-hardwood } \\
\text { cutting }\end{array}$ & 24.54 & 17.08 & 2.87 & 6.80 & 3.25 & 7.50 & 8.73 & 12.12 \\
\hline $\mathrm{C}_{3}$ Hardwood cutting & 24.47 & 25.69 & 3.15 & 10.09 & 3.89 & 8.81 & 9.46 & 14.72 \\
\hline S.Em \pm & 0.34 & 0.41 & 0.04 & 0.05 & 0.04 & 0.07 & 0.07 & 0.05 \\
\hline CD $(5 \%)$ & 1.02 & 1.22 & 0.13 & 0.15 & 0.12 & 0.20 & 0.22 & 0.16 \\
\hline$M_{1}$ Sand & 24.62 & 20.00 & 2.63 & 7.50 & 3.79 & 6.09 & 7.81 & 12.67 \\
\hline $\mathbf{M}_{2}$ Soilrite & 24.59 & 22.22 & 2.94 & 6.05 & 3.15 & 6.68 & 9.81 & 13.63 \\
\hline $\mathbf{M}_{3}$ Soil mixture & 24.31 & 17.59 & 3.00 & 5.73 & 3.25 & 8.02 & 10.52 & 15.95 \\
\hline $\mathrm{M}_{4}$ Cocopeat & 24.28 & 21.48 & 2.85 & 8.30 & 3.45 & 8.76 & 8.72 & 12.81 \\
\hline S.Em \pm & 0.39 & 0.47 & 0.05 & 0.06 & 0.05 & 0.08 & 0.09 & 0.06 \\
\hline CD (5\%) & 1.17 & 1.40 & 0.15 & 0.17 & 0.14 & 0.23 & 0.26 & 0.19 \\
\hline G $_{0}$ IBA 0 ppm & 24.64 & 18.05 & 2.62 & 6.74 & 3.54 & 6.93 & 9.15 & 12.80 \\
\hline $\mathrm{G}_{1}$ IBA 500 ppm & 24.83 & 23.84 & 2.99 & 7.72 & 3.50 & 7.31 & 8.92 & 15.06 \\
\hline $\mathrm{G}_{2}$ IBA $1,000 \mathrm{ppm}$ & 23.70 & 18.29 & 2.79 & 6.38 & 3.32 & 7.26 & 8.75 & 13.79 \\
\hline $\mathrm{G}_{3}$ IBA $1,500 \mathrm{ppm}$ & 24.67 & 20.60 & 2.97 & 6.77 & 3.35 & 7.53 & 9.24 & 12.80 \\
\hline $\mathbf{G}_{4}$ Rootex & 24.41 & 20.83 & 2.90 & 6.85 & 3.34 & 7.91 & 10.02 & 14.37 \\
\hline S.Em \pm & 0.44 & 0.52 & 0.05 & 0.06 & 0.05 & 0.09 & 0.10 & 0.07 \\
\hline CD (5\%) & 1.31 & 1.57 & 0.16 & 0.19 & 0.16 & 0.26 & 0.29 & 0.21 \\
\hline
\end{tabular}


Table.2 Shoot and root parameters as influenced by types of cuttings, growing media and various concentrations of plant growth regulators

\begin{tabular}{|c|c|c|c|c|c|c|c|c|}
\hline \multirow[t]{2}{*}{ Factors } & \multicolumn{3}{|c|}{ Shoot length (in cm) } & \multirow{2}{*}{$\begin{array}{c}\text { Fresh } \\
\text { weight } \\
\text { (in g) }\end{array}$} & \multirow{2}{*}{$\begin{array}{c}\text { Dry } \\
\text { weight } \\
\text { (in g) }\end{array}$} & \multirow{2}{*}{$\begin{array}{l}\text { Number of } \\
\text { primary root }\end{array}$} & \multirow{2}{*}{$\begin{array}{l}\text { Longest root } \\
\text { length(in } \mathrm{cm})\end{array}$} & \multirow{2}{*}{$\begin{array}{c}\text { Rooting } \\
\text { percentage }\end{array}$} \\
\hline & 30 DAP & 60 DAP & 90 DAP & & & & & \\
\hline $\mathrm{C}_{1}$ Shoot-tip cuttings & 1.29 & 4.41 & 6.10 & 3.23 & 2.46 & 5.12 & 6.93 & 16.25 \\
\hline $\begin{array}{c}\mathrm{C}_{2} \text { Semi-hardwood } \\
\text { cutting }\end{array}$ & 1.14 & 3.94 & 6.23 & 3.82 & 2.94 & 4.17 & 8.80 & 15.83 \\
\hline $\mathrm{C}_{3}$ Hardwood cutting & 1.38 & 3.76 & 8.15 & 5.95 & 4.62 & 5.62 & 10.26 & 24.44 \\
\hline S.Em \pm & 0.01 & 0.09 & 0.03 & 0.02 & 0.01 & 0.03 & 0.02 & 0.35 \\
\hline CD $(5 \%)$ & 0.03 & 0.27 & 0.10 & 0.06 & 0.03 & 0.10 & 0.06 & 1.04 \\
\hline$M_{1}$ Sand & 1.07 & 3.58 & 5.63 & 3.80 & 3.00 & 4.51 & 9.07 & 18.14 \\
\hline$M_{2}$ Soilrite & 1.00 & 3.72 & 6.15 & 4.27 & 3.27 & 4.85 & 7.43 & 20.92 \\
\hline $\mathbf{M}_{3}$ Soil mixture & 1.47 & 4.57 & 7.83 & 3.68 & 2.85 & 5.30 & 8.50 & 16.48 \\
\hline $\mathrm{M}_{4}$ Cocopeat & 1.53 & 4.29 & 7.70 & 5.60 & 4.23 & 5.23 & 9.65 & 19.81 \\
\hline S.Em \pm & 0.01 & 0.10 & 0.04 & 0.02 & 0.01 & 0.04 & 0.02 & 0.40 \\
\hline CD $(5 \%)$ & 0.03 & 0.31 & 0.11 & 0.07 & 0.04 & 0.12 & 0.07 & 1.20 \\
\hline G $_{0}$ IBA 0 ppm & 1.15 & 3.72 & 6.07 & 4.00 & 3.09 & 4.41 & 7.80 & 16.20 \\
\hline G $_{1}$ IBA 500 ppm & 1.30 & 4.21 & 7.07 & 4.83 & 3.69 & 5.32 & 8.85 & 21.29 \\
\hline $\mathrm{G}_{2}$ IBA $1,000 \mathrm{ppm}$ & 1.29 & 4.01 & 6.99 & 4.15 & 3.17 & 4.88 & 8.56 & 17.59 \\
\hline $\mathrm{G}_{3}$ IBA $1,500 \mathrm{ppm}$ & 1.30 & 4.35 & 7.06 & 4.28 & 3.31 & 5.04 & 9.10 & 19.67 \\
\hline $\mathbf{G}_{4}$ Rootex & 1.30 & 3.89 & 6.96 & 4.42 & 3.42 & 5.22 & 8.99 & 19.44 \\
\hline S.Em \pm & 0.01 & 0.12 & 0.04 & 0.02 & 0.01 & 0.04 & 0.02 & 0.45 \\
\hline CD $(5 \%)$ & 0.04 & 0.35 & 0.13 & 0.07 & 0.04 & 0.13 & 0.07 & 1.34 \\
\hline
\end{tabular}


Table.3 Shoot and root parameters as influenced by type of cutting, growing media and plant growth regulators

\begin{tabular}{|c|c|c|c|c|c|c|c|c|c|c|}
\hline \multirow{2}{*}{$\begin{array}{c}\text { S. } \\
\text { No. }\end{array}$} & \multirow[t]{2}{*}{ Treatment } & \multirow{2}{*}{$\begin{array}{c}\text { Treatment } \\
\text { details }\end{array}$} & \multirow{2}{*}{$\begin{array}{l}\text { Days taken } \\
\text { for sprout } \\
\text { initiation }\end{array}$} & \multirow{2}{*}{$\begin{array}{l}\text { Sprouting } \\
\text { percentage }\end{array}$} & \multicolumn{3}{|c|}{ Shoot length(in cm) } & \multirow{2}{*}{$\begin{array}{c}\text { Number of } \\
\text { primary root }\end{array}$} & \multirow{2}{*}{$\begin{array}{l}\text { Length of } \\
\text { longest root (in } \\
\text { cm) }\end{array}$} & \multirow{2}{*}{$\begin{array}{c}\text { Rooting } \\
\text { percentage }\end{array}$} \\
\hline & & & & & 30 DAP & 60 DAP & 90 DAP & & & \\
\hline 1 & $\mathrm{~T}_{1}$ & $\mathrm{C}_{1}+\mathrm{M}_{1}+\mathrm{G}_{0}$ & 23.20 & 16.66 & 1.02 & 4.00 & 5.08 & 3.17 & 5.50 & 13.89 \\
\hline 2 & $\mathrm{~T}_{2}$ & $\mathrm{C}_{1}+\mathrm{M}_{1}+\mathrm{G}_{1}$ & 23.27 & 22.22 & 1.14 & 4.03 & 4.90 & 4.38 & 5.88 & 19.44 \\
\hline 3 & $\mathrm{~T}_{3}$ & $\mathrm{C}_{1}+\mathrm{M}_{1}+\mathrm{G}_{2}$ & 23.46 & 22.22 & 0.68 & 2.43 & 5.05 & 5.13 & 5.33 & 22.22 \\
\hline 4 & $\mathrm{~T}_{4}$ & $\mathrm{C}_{1}+\mathrm{M}_{1}+\mathrm{G}_{3}$ & 25.50 & 16.66 & 0.83 & 2.75 & 5.08 & 3.63 & 5.38 & 16.66 \\
\hline 5 & $\mathrm{~T}_{5}$ & $\mathrm{C}_{1}+\mathrm{M}_{1}+\mathrm{G}_{4}$ & 25.63 & 16.66 & 0.78 & 2.60 & 5.27 & 3.17 & 5.05 & 13.89 \\
\hline 6 & $\mathrm{~T}_{6}$ & $\mathrm{C}_{2}+\mathrm{M}_{1}+\mathrm{G}_{0}$ & 26.25 & 22.22 & 1.25 & 2.79 & 5.33 & 5.38 & 6.33 & 19.44 \\
\hline 7 & $\mathrm{~T} 7$ & $\mathrm{C}_{2}+\mathrm{M}_{1}+\mathrm{G}_{1}$ & 26.75 & 16.66 & 0.75 & 3.13 & 5.65 & 6.17 & 7.18 & 13.89 \\
\hline 8 & $\mathrm{~T}_{8}$ & $\mathrm{C}_{2}+\mathrm{M}_{1}+\mathrm{G}_{2}$ & 24.42 & 16.66 & 0.95 & 4.57 & 5.53 & 6.46 & 6.51 & 16.66 \\
\hline 9 & $\mathrm{~T}_{9}$ & $\mathrm{C}_{2}+\mathrm{M}_{1}+\mathrm{G}_{3}$ & 21.83 & 22.22 & 0.84 & 4.51 & 5.56 & 4.38 & 6.23 & 22.22 \\
\hline 10 & $\mathrm{~T}_{10}$ & $\mathrm{C}_{2}+\mathrm{M}_{1}+\mathrm{G}_{4}$ & 20.67 & 22.22 & 0.94 & 4.91 & 5.76 & 4.13 & 6.33 & 16.66 \\
\hline 11 & $\mathrm{~T}_{11}$ & $\mathrm{C}_{3}+\mathrm{M}_{1}+\mathrm{G}_{0}$ & 16.83 & 16.66 & 1.79 & 4.92 & 5.93 & 5.29 & 6.47 & 11.11 \\
\hline 12 & $\mathrm{~T}_{12}$ & $\mathrm{C}_{3}+\mathrm{M}_{1}+\mathrm{G}_{1}$ & 22.83 & 27.77 & 2.14 & 6.67 & 7.25 & 5.45 & 7.24 & 25.00 \\
\hline 13 & $\mathrm{~T}_{13}$ & $\mathrm{C}_{3}+\mathrm{M}_{1}+\mathrm{G}_{2}$ & 26.50 & 16.66 & 1.80 & 6.02 & 7.71 & 5.63 & 6.77 & 16.66 \\
\hline 14 & $\mathrm{~T}_{14}$ & $\mathrm{C}_{3}+\mathrm{M}_{1}+\mathrm{G}_{3}$ & 26.58 & 11.11 & 1.33 & 8.05 & 11.13 & 8.75 & 11.13 & 11.11 \\
\hline 15 & $\mathrm{~T}_{15}$ & $\mathrm{C}_{3}+\mathrm{M}_{1}+\mathrm{G}_{4}$ & 28.25 & 19.44 & 1.52 & 6.50 & 8.36 & 10.17 & 9.82 & 16.66 \\
\hline 16 & $\mathrm{~T}_{16}$ & $\mathrm{C}_{1}+\mathrm{M}_{2}+\mathrm{G}_{0}$ & 24.50 & 11.11 & 2.15 & 5.00 & 6.38 & 4.25 & 5.45 & 11.11 \\
\hline 17 & $\mathrm{~T}_{17}$ & $\mathrm{C}_{1}+\mathrm{M}_{2}+\mathrm{G}_{1}$ & 22.08 & 19.44 & 1.76 & 3.43 & 4.93 & 4.00 & 8.88 & 16.66 \\
\hline 18 & $\mathrm{~T}_{18}$ & $\mathrm{C}_{1}+\mathrm{M}_{2}+\mathrm{G}_{2}$ & 22.92 & 13.89 & 1.18 & 3.51 & 5.06 & 3.58 & 7.35 & 11.11 \\
\hline 19 & $\mathrm{~T}_{19}$ & $\mathrm{C}_{1}+\mathrm{M}_{2}+\mathrm{G}_{3}$ & 28.92 & 16.66 & 1.58 & 4.48 & 6.33 & 4.50 & 8.15 & 13.89 \\
\hline 20 & $\mathrm{~T}_{20}$ & $\mathrm{C}_{1}+\mathrm{M}_{2}+\mathrm{G}_{4}$ & 26.00 & 16.66 & 1.45 & 4.00 & 5.78 & 4.83 & 7.60 & 16.66 \\
\hline 21 & $\mathrm{~T}_{21}$ & $\mathrm{C}_{2}+\mathrm{M}_{2}+\mathrm{G}_{0}$ & 29.33 & 19.44 & 0.79 & 2.70 & 5.19 & 3.63 & 10.21 & 16.66 \\
\hline 22 & $\mathrm{~T}_{22}$ & $\mathrm{C}_{2}+\mathrm{M}_{2}+\mathrm{G}_{1}$ & 29.83 & 25.00 & 1.11 & 4.61 & 5.55 & 5.13 & 11.10 & 22.22 \\
\hline 23 & $\mathrm{~T}_{23}$ & $\mathrm{C}_{2}+\mathrm{M}_{2}+\mathrm{G}_{2}$ & 24.75 & 19.44 & 1.15 & 3.80 & 5.90 & 6.13 & 11.21 & 16.66 \\
\hline 24 & $\mathrm{~T}_{24}$ & $\mathrm{C}_{2}+\mathrm{M}_{2}+\mathrm{G}_{3}$ & 19.90 & 22.22 & 1.45 & 5.23 & 6.19 & 6.10 & 10.41 & 22.22 \\
\hline 25 & $\mathrm{~T}_{25}$ & $\mathrm{C}_{2}+\mathrm{M}_{2}+\mathrm{G}_{4}$ & 21.88 & 25.00 & 1.03 & 4.89 & 9.30 & 5.43 & 11.46 & 22.22 \\
\hline 26 & $\mathrm{~T}_{26}$ & $\mathrm{C}_{3}+\mathrm{M}_{2}+\mathrm{G}_{0}$ & 27.53 & 16.66 & 0.58 & 4.73 & 6.21 & 4.88 & 10.73 & 13.89 \\
\hline 27 & $\mathrm{~T}_{27}$ & $\mathrm{C}_{3}+\mathrm{M}_{2}+\mathrm{G}_{1}$ & 24.54 & 36.11 & 1.33 & 5.74 & 10.79 & 4.13 & 9.64 & 33.33 \\
\hline 28 & $\mathrm{~T}_{28}$ & $\mathrm{C}_{3}+\mathrm{M}_{2}+\mathrm{G}_{2}$ & 20.95 & 19.44 & 1.48 & 5.02 & 9.02 & 5.46 & 9.25 & 19.44 \\
\hline 29 & $\mathrm{~T}_{29}$ & $\mathrm{C}_{3}+\mathrm{M}_{2}+\mathrm{G}_{3}$ & 25.63 & 19.44 & 1.95 & 4.85 & 8.95 & 5.88 & 10.50 & 19.44 \\
\hline 30 & $\mathrm{~T}_{30}$ & $\mathrm{C}_{3}+\mathrm{M}_{2}+\mathrm{G}_{4}$ & 26.25 & 13.89 & 1.85 & 3.67 & 5.30 & 3.83 & 9.90 & 13.89 \\
\hline 31 & $\mathrm{~T}_{31}$ & $\mathrm{C}_{1}+\mathrm{M}_{3}+\mathrm{G}_{0}$ & 23.20 & 5.55 & 0.75 & 2.65 & 5.25 & 1.00 & 4.55 & 5.55 \\
\hline 32 & $\mathrm{~T}_{32}$ & $\mathrm{C}_{1}+\mathrm{M}_{3}+\mathrm{G}_{1}$ & 23.10 & 8.33 & 1.23 & 3.13 & 5.35 & 1.50 & 5.10 & 8.33 \\
\hline
\end{tabular}


Int.J.Curr.Microbiol.App.Sci (2019) 8(10): 2589-2605

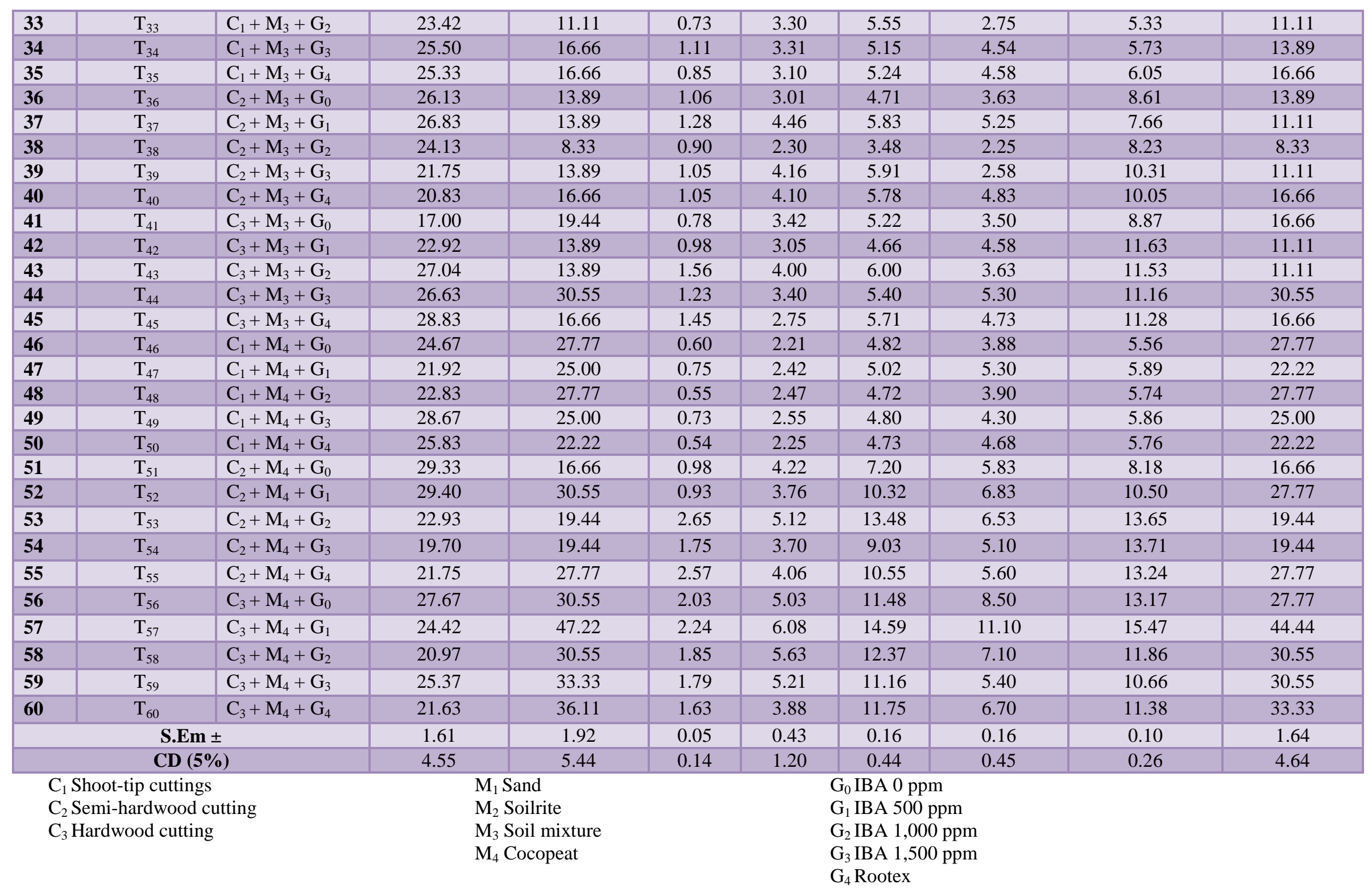


Fig.1 Number of sprouts as influenced by type of cutting, growing media and plant growth regulators

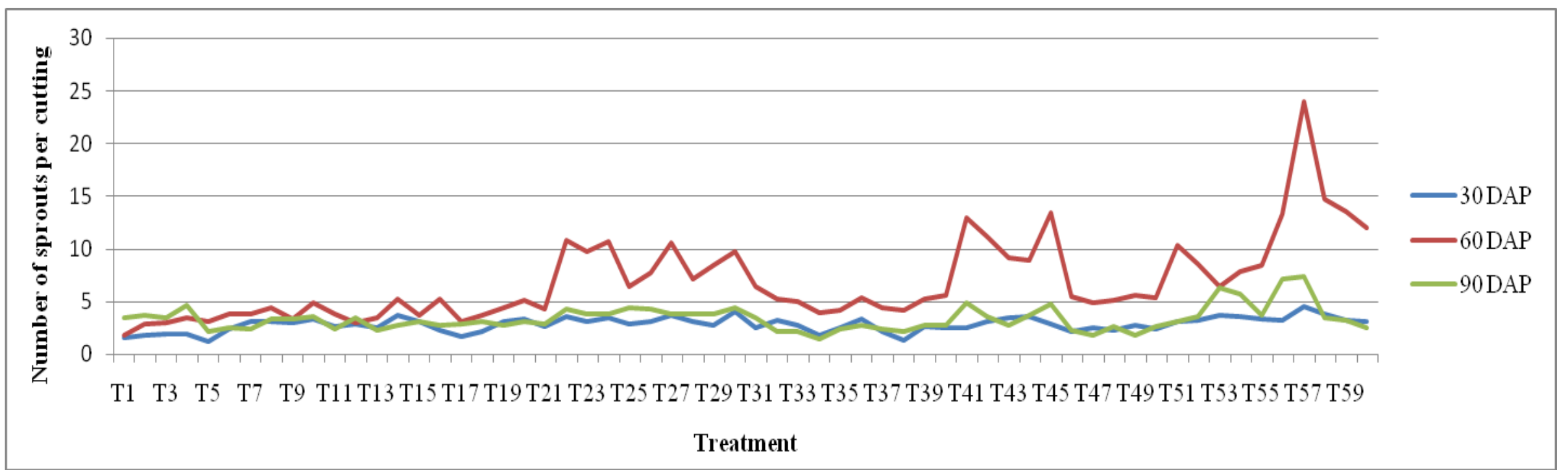

Fig.2 Number of leaves as influenced by type of cutting, growing media and plant growth regulators

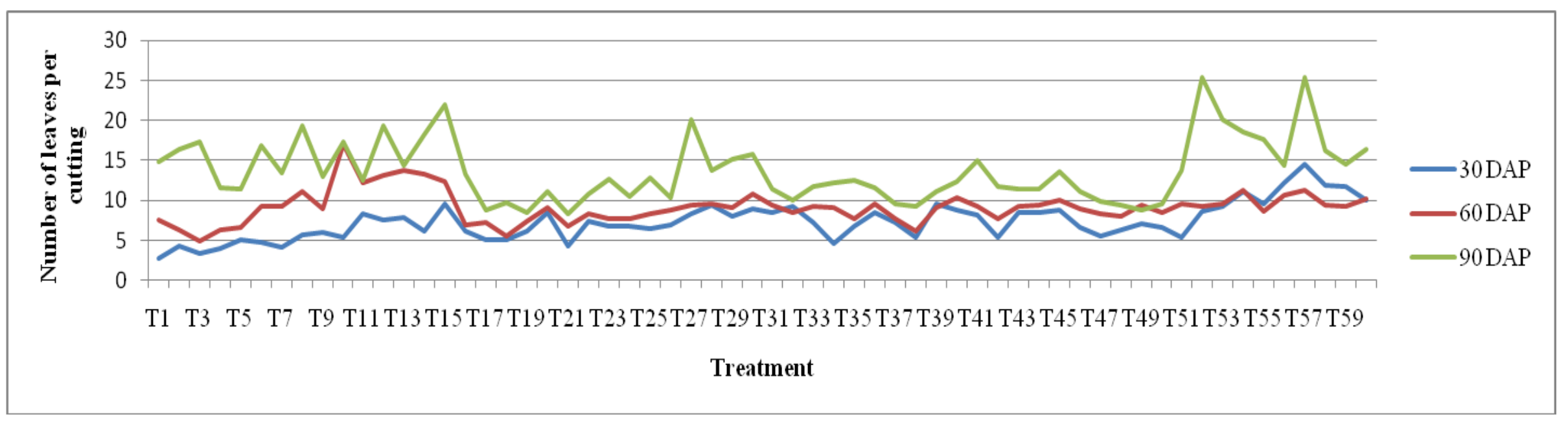


Fig.3 Fresh weight and dry weight at 90 DAP as influenced by type of cutting, growing media and plant growth regulators

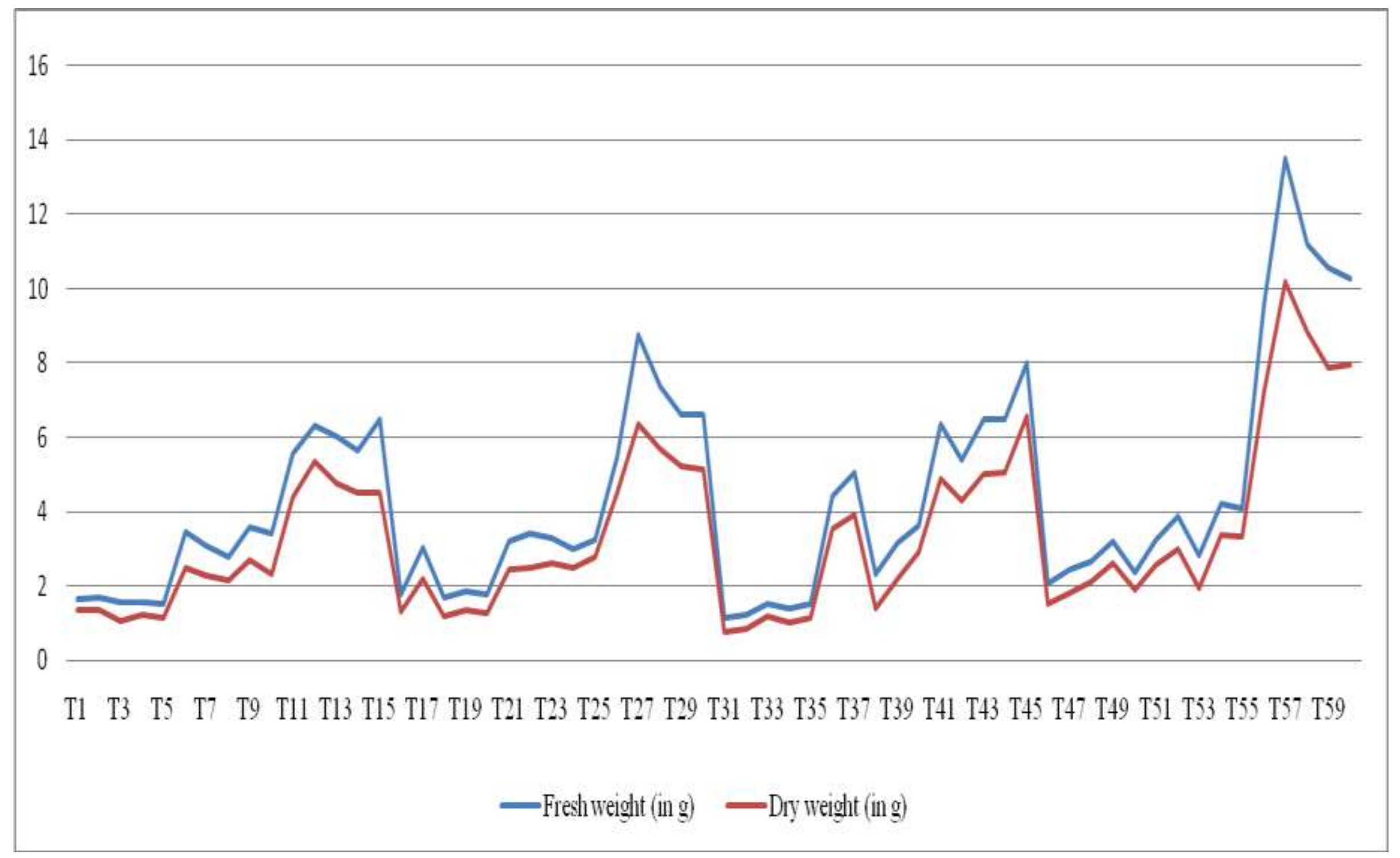


Further, similar findings had been also obtained by Al-Zebari et al., (2013) in Citron (Citrus medica L).

\section{Effect on shoot length}

The shoot length $(\mathrm{cm})$ was increased up to 90 DAP and was found significant among the treatments (Table 1). Hardwood cuttings were better than other types of cutting because it had longer primary roots which resulted efficient nutrient uptake, coco-peat and soilrite media had performed better than other media as these media were porous, hence, more growth of roots had taken place and 500 ppm IBA was better towards inducing higher shoot length in cuttings.

The shoot length $(\mathrm{cm})$ was increased utp to 90 DAP and was found significant among the treatments due interaction of factors (Table $3)$. Longest average length of shoot at 90 DAP was observed in the treatment $T_{57}\left(C_{3}\right.$ hardwood cutting $+\mathrm{M}_{4}$ cocopeat $+\mathrm{G}_{1}$ IBA $500 \mathrm{ppm}$ ) with $14.59 \mathrm{~cm}$ long shoots, whereas, shortest average length of shoot was recorded in $\mathrm{T}_{38}\left(\mathrm{C}_{2}\right.$ semi-hardwood cutting+ $\mathrm{M}_{3}$ soil mixture $+\mathrm{G}_{2}$ IBA $1,000 \mathrm{ppm}$ ) with $3.475 \mathrm{~cm}$.

There was steady increase in shoot length in cuttings survived in the experiment. Similarly, El-Shazly et al., (1994) reported shoot length/cutting to be $22.60-23.50 \mathrm{~cm}$ in cuttings of lemon cv. Eureka $(25 \mathrm{~cm}$ long with 4-5 leaves) treated with 4000 ppm IBA. Sadiq (1991) had got an average shoot length of $7.5 \mathrm{~cm}$ in semi-hardwood stems cuttings of peach cv. Early Grande found treated with 400 ppm of IBA. Awan et al., (2012) obtained a shoot length of $22.29 \mathrm{~cm}$ in olive cultivar Azerbaijan at $20 \mathrm{~cm}$ cuttings length.

These findings were also in confirmation with Al-zebari et al., (2013) in Citron (Citrus medica $\mathrm{L}$ ) cuttings.

\section{Effect on fresh weight}

In this study, hardwood cuttings produced significantly more fresh weight as compared to other types of cutting as the diameter was more in case of hardwood cuttings (Table 2), the cuttings planted in the coco peat and soilrite media had produced more average fresh weight than other media as these media provided efficient supply of nutrient and the cuttings treated with $500 \mathrm{ppm}$ of IBA and rootex were produced more average fresh weight. The fresh weight (g) after 90 DAP was found significant among the treatments due to the interaction effect of type of cutting, growing media and growth regulator (IBA) (Fig. 3). The highest average fresh weight at 90 days after planting had been recorded in the treatment $\mathrm{T}_{57}\left(\mathrm{C}_{3}\right.$ hardwood cutting $+\mathrm{M}_{4}$ cocopeat $+\mathrm{G}_{1}$ IBA $500 \mathrm{ppm}$ ) with $13.52 \mathrm{~g}$ and the lowest average fresh weight was recorded in $T_{31}\left(C_{1}\right.$ shoot-tip cuttings $+M_{3}$ soil mixture $+\mathrm{G}_{0}$ IBA 0 ppm) with $1.15 \mathrm{~g}$. Similarly, Hakim et al., (2018) reported fresh weight of shoots (10.80 and $12.60 \mathrm{~g})$ treated with with IBA 1500 ppm + NAA 1500 ppm + Biomix in pomegranate (Punica granatum L.) cuttings cvs. Bhagwa and Ruby, repectively. These findings are also in confirmation with the studies of Singh et al., (2015) in lemon (Citrus limon L.) cuttings.

\section{Effect on dry weight}

In this study, the highest average dry weight had been recorded in the hardwood cuttings (Table 2) as the diameter of cuttings were more, in the coco peat and soilrite media than other media as these media provided efficient supply of nutrient and the in $500 \mathrm{ppm}$ of IBA and rootex than other levels of growth regulators. Significant differences were recorded among the treatments on dry weight (g) after 90 days of planting due to effect of type of cutting, growing media and growth regulator (Fig. 3). Highest average dry weight 
of cuttings at 90 days after planting was recorded in the treatment $\mathrm{T}_{57}\left(\mathrm{C}_{3}\right.$ hardwood cutting $+\mathrm{M}_{4}$ cocopeat $+\mathrm{G}_{1}$ IBA $500 \mathrm{ppm}$ ) of about $10.19 \mathrm{~g}$ and lowest average dry weight was recorded in $T_{31}\left(C_{1}\right.$ shoot-tip cuttings + $\mathrm{M}_{3}$ soil mixture $+\mathrm{G}_{0}$ IBA 0 ppm) with 0.775 g. Similarly, Singh et al., (2015) reported average dry weight of cutting $(8.05 \mathrm{~g})$ in case of lemon (Citrus limon Burm.) cv. pant lemon-1 planted in Soil+Sand+Cocopeat media. Further, Ahmad et al., (2016) suggested that treating Dragon fruit (Hylocereus undatus) stem cuttings with $100 \mathrm{ppm}$ of IBA solution is best for increased dry weight $(0.8 \mathrm{~g})$. The findings of our study are also in confirmation with the report of Hakim et al., (2018) in pomegranate cuttings.

\section{Effect on number of primary root}

In this study, highest average number of primary roots was recorded in the hardwood cuttings (Table 2) than other cuttings as the dry matter of cuttings were more, the cuttings planted in the coco peat and soilrite media produced more average number of primary roots than other media as these media provided efficient supply of nutrient and 500 ppm of IBA treated cuttings performed better for increasing the number of primary roots per cutting. Significant differences were present in number of primary root at 90 DAP among the treatments due to the interaction effect of type of cutting, types of media and IBA (Table 3). Highest average number of primary root per cutting were recorded in $\mathrm{T}_{57}\left(\mathrm{C}_{3}\right.$ hardwood cutting $+\mathrm{M}_{4}$ cocopeat $+\mathrm{G}_{1}$ IBA $500 \mathrm{ppm}$ ) with 11.10 roots and the lowest average number of roots was observed in the treatment $\mathrm{T}_{31}\left(\mathrm{C}_{1}\right.$ shoot-tip cuttings $+\mathrm{M}_{3}$ soil mixture $+\mathrm{G}_{0}$ IBA $0 \mathrm{ppm}$ ) with 1.0 root. Similarly, Awan et al., (2012) obtained maximum number of roots (15.39) in hardwood stem cuttings in olive cultivar Azarbaijan at $15 \mathrm{~cm}$ cuttings length. Similar findings had been obtained by Sabbah et al.,
(1991) in citrus related genera and intergeneric hybrids.

\section{Effect on Length of longest root}

In this study, highest length of longest primary root was recorded in the hardwood cuttings than other cuttings (Table 2), in the cocopeat and sand than other media and in $500 \mathrm{ppm}$ of IBA followed IBA 1500 ppm compared to other growth regulators levels. The optimum dose of IBA (500 ppm) and cocopeat and sand media significantly favoured length of longest root due to the assimilation and translocation of auxin compound in rooted cutting and well drained media is also promoted the better development of roots by penetration of roots. Significant differences were present in length of longest root at 90 DAP among the treatments due to the interaction effect of type of cutting, types of media and growth regulator (IBA) (Table 3). The highest average length of longest root per cutting had been recorded in $\mathrm{T}_{57}\left(\mathrm{C}_{3}\right.$ hardwood cutting+ $\mathrm{M}_{4}$ cocopeat $+\mathrm{G}_{1}$ IBA $500 \mathrm{ppm}$ ) with 15.47 $\mathrm{cm}$ and the lowest average length of primary roots was observed in the treatment $T_{31}\left(C_{1}\right.$ shoot-tip cuttings $+\mathrm{M}_{3}$ soil mixture $+\mathrm{G}_{0}$ IBA $0 \mathrm{ppm}$ ) with $4.55 \mathrm{~cm}$. However, Singh and Singh (2016) obtained longest length of roots $(13.63 \mathrm{~cm})$ in semi-hardwood cuttings of sweet orange (Citrus sinensis L. Osbeck) cv. Malta treated with $5000 \mathrm{ppm}$ of IBA. But similar views to our study were held by Murkute et al., (2009) in trifoliate orange (Poncirus trifoliata).

\section{Rooting percentage}

In this study, significantly, higher percentage of rooting was recorded in the hardwood cuttings (Table 2), high percentage of rooting was observed in soil mixture and coco-peat media compared to other media and high percentage of rooting was observed in 
cuttings treated with 500 ppm IBA. The variation in response with respect to different treatment was may be due to ability of cuttings to withstand the conditions, inherent growth regulators, etc. In addition to that when growth regulators were being used for boosting the rooting of cuttings could be attributed by the favourable conditions like optimum temperature $\left(25-30^{\circ} \mathrm{C}\right)$ and high relative humidity (80-90\%) which could promote better rooting in cutting. The percentage of rooted cuttings was significantly affected by interaction of different types of cuttings, growing media and various concentrations of IBA (Table 3; Plate 1). Highest rooting had been observed in treatment $\mathrm{T}_{57}\left(\mathrm{C}_{3}\right.$ hardwood cutting+ $\mathrm{M}_{4}$ cocopeat $+\mathrm{G}_{1}$ IBA $500 \mathrm{ppm}$ ) with 44.44 per cent, whereas lowest rooting percentage had been observed in treatment $T_{31}\left(C_{1}\right.$ shoot-tip cuttings $+\mathrm{M}_{3}$ soil mixture $+\mathrm{G}_{0}$ IBA 0 ppm) with 5.55 per cent. Similarly, Vijayakumar (1973) obtained 84.5 per cent rooting by treating the stem cuttings of guava by with 5000 ppm IBA and planting in the month of July. Further, Singh and Singh (2016) reported 71.67 per cent rooted cuttings in cuttings of sweet orange (Citrus sinensis L. Osbeck) cv. Malta under Mist. These results are in close confirmiy with of the earlier work by Karadeniz (2003) in hard wood cuttings of local fig cultivars.

In conclusion, the study showed that hardwood cuttings, cocopeat and 500 ppm IBA was better to induce more shooting and rooting parameters in acid lime Cv. Kagzi lime. The results obtained from this study can be used to develop a protocol for production of quality planting material of acid lime through cuttings.

\section{References}

Ahmad, H., Mirana, A.S., Mahbuba, S., Tareq, S.M. and Jamal Uddin, A.F.M.,
2016, Performance of IBA concentrations for rooting of dragon fruit (Hylocereus undatus) stem cuttings. International J. Bus. Soc. Sci. Res., 4(4): 231-234.

Al-Zebari, S.M.K. and Al-Brifkany, A.A.R.A.M., 2013, Effect of cutting type and IBA on rooting and growth of Citron (Citrus medica L). American J. Exp. Agric., 5(2): 134-138.

Anonymous, 2017, NHB database, nhb.gov.in/statistics/publication, pp 180-182.

Awan, A.A., Ullah, E., Abbas, S.J., Khan, O. and Masroor, S., 2012, Growth response of various olive cultivars to different cutting lengths. Pakistan J. Agri. Sci., 49(3): 315-318.

Babu, R. S. H., 2001, Limes and Lemons. In: Chadha, KL ed. Handbook of Horticulture. ICAR, New Delhi., pp.212.

Bhatt B.B. and Tomar Y.K., 2011, Effect of IBA and growing conditions on vegetative performance of Citrus aurantifolia (Swingle) cuttings. J. Hill Agric., 2(1): 98-101.

El-Shazly, S. M., El-Sabrout, M. B. and Kassem, H. A., 1994, Root formation on the stem cuttings of Eureka lemon and El-Soukari loquat as affected by root- promoting chemicals and mist. Alexandria J. Agril. Res., 39(3):559569.

Frey, B., Hagedorn, F. and Gludici, F., 2006, Effect of girdling on soil respiration and root composition in sweet chestnut forest. For. Ecol. Manage., 225 (13):271- 277.

Gomez, K.A. and Gomez, A.A., 1980, Statistical procedures for Agricultural Research. Indian Agricultural Research Institute Publication, New Delhi.

Hakim, A., Jaganath, S., Honnabyraiah, M.K., Kumar, S. M., Kumar, S. A. and Dayamani, K.J., 2018, Influence of 
biofertilizer and auxin on growth and rooting of pomegranate (Punica granatum L.) cuttings. Int. J. Curr. Microbiol. App. Sci., 7(2): 1187-1193.

Hakim, A., Jaganath, S., Honnabyraiah, M.K., Mohan S.K., Anil S.K. and Dayamani, K.J., 2018, Effect of biofertilizers and auxin on total chlorophyll content of leaf and leaf area in pomegranate (Punica granatum L.) cuttings. International J. Pure App. Biosci., 6(1): 987-99.

Hussain, I., Nabi, G., Rehman, H., Shah, K. and Ali, S., 2016, Effect of different environmental condition on different types of sweet lime cuttings. Pure Appl. Biol., 5(2): 298-302.

Karadeniz, T., 2003, A study on some fruit characteristics and propagation of these by hard wood cuttings of local fig cultivars grown in Ordu (Turkey). Acta Hort., 605: 107-112.

Kareem, A., Manan, A., Saeed, S., Rehman, S., Shahzad, U. and Nafees, M., 2016, Effect of different concentrations of IBA on rooting of Guava (Psidium guajava L.) in low tunnel under shady situation. J. Agric. Environ. Int. Dev., 110(2): 197-203.

Kumar, R., Gill, D.S. and Kaushik, R.A., 1995, Effect of indole butyric acid, phydroxybenzoic acid and season on the propagation of lemon cv. Baramasi from cuttings. Haryana J. Hortic. Sci., 24(1):13-18.

Mehta, S.K., Singh, K.K. and Harsana, A.S., 2018, Effect of IBA concentration and time of planting on rooting in pomegranate (Punica granatum) cuttings. J. Med. Plant Stud., 6(1): 250253.

Murkute, A. A., Sharma, S. and Singh, S. K., 2009, Micropropagation of trifoliate orange (Poncirus trifoliata). Indian $J$. Pl. Physiol., 14(2):190-193.

Sabbah, S.M., Grosser, J.W., Chandler, J.L. and Louzada, E.S., 1991, The effect of growth regulators on the rooting of Citrus related genera and intergeneric hybrids. Proc. Fla. State Hort. Soc., 104: 188-191.

Sadiq, W.M., Shah, S.F. and Afsarullah, 1991, Effect of different concentrations of IBA on initiation of roots in the cuttings of peach cv. Early Grande. Sarhad J. Agric., 7 (1): 53-57.

Seran, T.H. and Umadevi, T., 2011, Influence of indole acetic acid (IAA) on the establishment of stem cuttings in lemon (Citrus limon L.). J. Agric. Res., 49(4): 517-524.

Siddiqui, M.I. and Hussain, S.A., 2007, Effect of indole butyric acid and types of cuttings on root initiation of Ficus hawaii. Sarhad J. Agric., 23(4): 919926.

Singh, K. K., Chauhan, J. S., Rawat, J.M.S. and Rana, D.K., 2015, Effect of different growing conditions and various concentrations of IBA on the rooting and shooting of hardwood cutting of phalsa (Grewia asiatica L.) under valley condition of garhwal 2604eticulat. Plant Archives, 15(1): 131-136.

Singh, K.K., 2014, Effect of iba concentrations on the rooting of pomegranate (Punica granatum L.) cv. Ganesh hardwood cuttings under mist house condition. Pl. Arch., 14(2): 11111114.

Singh, S. and Singh, K. K., 2016, Effect of various concentrations of IBA and Type of stem cuttings on the performance of rooting in sweet orange (Citrus sinensis Osbeck) cv. Malta under mist-house. The Bioscan, 11(2): 903-906.

Vijayakumar, N., 1973, Studies on the propagation of guava (Psidium guajava L.) by cuttings. Ph.D., thesis submitted to the University of Udaipur.

Yadav, R.K., Jain, M. C. and Jhakar, R. P., 
2012, Effect of media on growth and development of acid lime (Citrus aurantifolia Swingle) seedling with or without Azotobacter. African J. Agric. Res., 7(48): 6421-6426.

\section{How to cite this article:}

Ashis Malakar, D. P. Prakasha, H. Kulapati, Sanjeevraddi G. Reddi, S. G. Gollagi, N. Anand and Satheesh, P. 2019. Effect of Growing Media and Plant Growth Regulators on Rooting of Different Types of Stem Cuttings in Acid-Lime Cv. Kagzi. Int.J.Curr.Microbiol.App.Sci. 8(10): 2589-2605. doi: https://doi.org/10.20546/ijcmas.2019.810.300 